\title{
Die boodskap van die Bybel tot getuienis in die wêreld
}

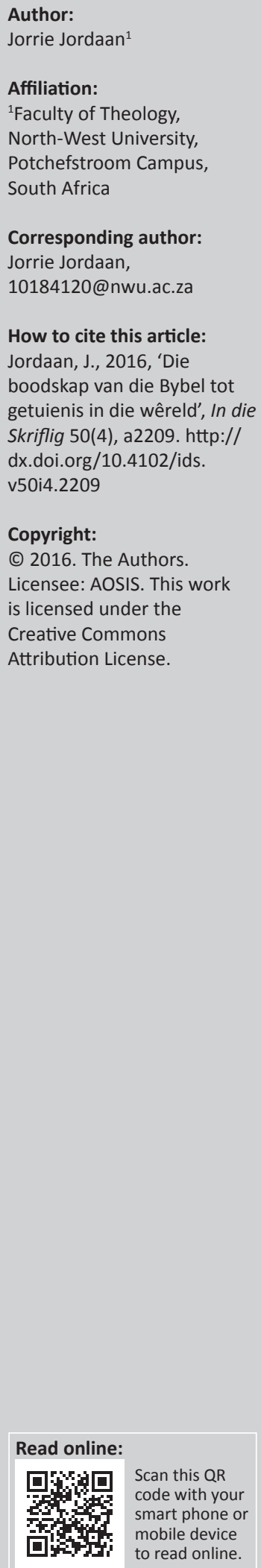

Met hierdie feesbundel word met dankbaarheid teruggekyk op die kosbare werk van prof. P.P. (Paul) Krüger oor die afgelope 16 jaar aan die Teologiese Skool Potchefstroom en die Fakulteit Teologie van die Noordwes-Universiteit (NWU). Paul het op 14 Junie 2016 die ouderdom van 65 bereik en emeriteer daarom volgens die ooreenkoms met die NWU aan die einde van 2016 as professor by die Teologiese Skool sowel as die NWU.

Paul het in 2000 gedoktoreer met die proefskrif getiteld: 'Die beskrywing van gedagte-samehang: 'n eksegetiese hulpmiddel, geillustreer aan die hand van Genesis 2'. Sedertdien het hy 'n kosbare bydrae op sy vakgebied gelewer deur verskeie wetenskaplike artikels in vaktydskrifte, hoofstukke in versamelbundels en talle wetenskaplike voordragte by nasionale en internasionale vakkonferensies.

Voor Paul in 2000 na die Teologiese Skool Potchefstroom beroep is en as professor in die Fakulteit Teologie van die NWU aangestel is, het hy gedien as predikant van die Gereformeerde Kerk Alberton-Wes (1979-1982), Brackenhurst (1982-1996) en Brackenhof (1996-2000). Oor die jare het hy op verskeie deputate van die GKSA se Algemene Sinode gedien en was veral betrokke by die bevordering van Christelike Onderwys deur onder meer leiding te gee by die Aksie Reformatoriese Skoolonderwys. Paul het met die jare verskeie populêr-teologiese boeke en artikels oor 'n wye verskeidenheid onderwerpe geskryf onder meer 'n groot aantal artikels in die kerklike tydskrifte van die GKSA. Hy was vir 'n termyn redaksielid van Die Kerkblad en van 2003 tot 2005 hoofredakteur van In die Skriflig.

Met dankbaarheid vir die mooi gawes wat die Here aan Paul gegee het wat tot opbou van die kerk en wetenskap gebruik kon word, is die volgende bydraes van kollegas en studente versamel vir hierdie festschrift wat aan Paul opgedra word. Hoewel die feesbundel nie rondom 'n geformuleerde tema beplan is nie, kan die verskeidenheid van bydraes saamgevoeg word onder die tema 'Die boodskap van die Bybel tot getuienis in die wêreld'.

H.F. (Herrie) van Rooy se bydrae bevat die resultate van sy ondersoek na bepaalde retoriese aspekte van die profesieë van Esegiël. Hoewel die retoriese doel en situasie van profetiese geskrifte al dikwels ondersoek is en steeds ondersoek word, bied hierdie artikel 'n nuwe aanslag. Dit bevat 'n poging om die oorspronklike retoriese situasie waarin die profeet spesifiek aanhalings gebruik en toegepas het, te rekonstrueer. Op hierdie manier slaag Van Rooy daarin om drie velde van $\mathrm{Ou}$ Testamentiese ondersoek by mekaar uit te bring: navorsing oor retoriese aspekte, oor aanhalings in die Bybel, en oor die sogenaamde twisgesprekke.

P.C. (Chris) van der Walt bied in sy bydrae vanuit Deuteronomium 20 'n bybelse perspektief op bepalings van die Geneefse Konvensie oor omgewingsbewaring. Veral die kwessie van verlenging van menselewens word onder die loep geneem. Deuteronomium 20 bied 'n perspektief op die verhouding tussen mens en natuur wat teen die destydse denke ingaan en wat ook hedendaagse konvensionele beskouings oor hierdie aangeleentheid sterk bevraagteken. Hierdie artikel toon die noodsaak aan van 'n paradigma-skuif weg van 'n antroposentriese houding jeens die natuur en die reg tot lewe. In die plek daarvan is 'n nuwe stel morele waardes nodig waarin die verlenging van menselewens nie belangriker beskou word as die behoud van die natuur nie.

Cynthia Miller-Naudé en Jacobus Naudé se bydrae gaan oor 'n aspek van die grammatika van bybelse Hebreeus. Dit sluit aan by die vraagstuk wat in verskeie werke oor Hebreeuse grammatika aan die orde kom, naamlik of byvoeglike naamwoorde in bybelse Hebreeus as 'n afsonderlike kategorie naas selfstandige naamwoorde beskou moet word of nie. Op grond van morfologiese en sintaktiese oorwegings kom hulle tot die gevolgtrekking dat selfstandige naamwoorde en byvoeglike naamwoorde in bybelse Hebreeus inderdaad afsonderlike leksikale kategorieë is en 
nie saam onder die sambreel-kategorie van 'substantief' of 'naamwoord' ingedeel moet word nie.

Paul J. de Bruyn en Ben de Klerk se bydrae hou verband met die praktiese inrigting van 'n predikant se dienswerk. Hulle artikel berus op die resultate van 'n proefskrif in Pastorale Teologie wat in 2015 gedien het waarin daar oor die effektiewe en verantwoordelike leierskap van Afrikaanse predikante besin word. Predikante in die Afrikaanse kerke beskik nie oor duidelik-omlynde riglyne oor wat van hulle as leiers in die kerk verwag word nie. Daarom word daar in hierdie artikel riglyne uit Paulus se leidinggewende optrede as apostel in die Nuwe Testament gehaal. Veral Paulus se mededelings in Filippense 3:1-16 is as vertrekpunt hiervoor geneem.

Paul R. McCuistion fokus in sy artikel op uitsprake in die Matteusevangelie oor die vervulling van Ou-Testamentiese profesieë oor die Messias. Hy begin by die eerste woorde van die Evangelie waarin Jesus as die Christus, die seun van Dawid en die seun van Abraham bekendgestel word (Matt 1:1). Dit word opgevolg deur 'n ondersoek van sewe

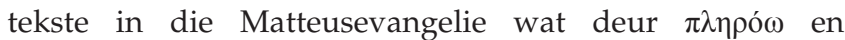
ander vervullingsformules ingelei word. Hy kom tot die gevolgtrekking dat Matteus die Ou-Testamentiese profesieë inderdaad in Christologiese sin verstaan en as bewysmateriaal gebruik om Jesus as die Messias bekend te stel.

Amanda du Plessis het in haar bydrae 'n ontleding van die Onse Vader-gebed gedoen met toepassing op die gebied van pastorale berading. Sy toon aan hoe iemand aan die hand van hierdie gebed in ' $n$ proses van berading begelei kan word om vanuit 'n probleem-gesentreerde houding oor te gaan na 'n lewe van geregtigheid, vrede en blydskap. In die artikel word veral twee hooftemas van die Onse Vader-gebed bespreek, naamlik die mens se verhouding met God en die mens se afhanklikheid van God. Sodoende word die Onse Vader-gebed aangebied as 'n paradigma vir die herstel van geregtigheid te midde van die gebrokenheid waarin die mens hom bevind.

Aida Spencer se bydrae is ' $n$ ondersoek na die linguistiese styl en retoriese aanslag van Paulus se toesprake in sy verdediging voor die hof in Caesarea soos dit in Handelinge 15 en 26 opgeteken is. Haar bevinding is dat die Grieks wat Paulus gebruik wanneer hy Festus en Agrippa in die hofsaak aanspreek, 'n besliste literêre styl vertoon waarin hy, bewustelik of onbewustelik, bepaalde grammatikale moontlikhede wat Koinê Grieks bevat, uitkies om daarmee beklemtoning, analogie en ander retoriese effekte te bereik.

Flip Buys en John Koning se bydrae hou verband met die uitdra van die evangelie in ' $n$ toenemend-verstedelikte samelewing wat in ' $n$ postmodernistiese denkklimaat bestaan. Vanuit'n studie van die prediking van Gereformeerde Baptiste en die Gereformeerde Kerke in Suid-Afrika, toon hulle aan dat die prediking in hierdie kerkgemeenskappe beslis toegewyd is aan die verkondiging van die bybelse waarheid en die regsinnige verdediging daarvan. Hulle bevind egter dat daar tog ' $n$ besliste leemte in en behoefte aan gegronde en effektiewe kontekstualisering van die Skrifboodskap bestaan - waarskynlik in weerstand teen die eensydige kontekstualisme van die liberale teologie. Die artikel sluit af met voorstelle vir gegronde kontekstualisering met die oog op 'n meer effektiewe uitreik na die postmodernistiese verstedelikte samelewing.

Pierre Jordaan se bydrae kom uit sy studie van die Ou-Testamentiese apokriewe geskrifte. Hy maak 'n analise van die rol van lydende liggame in die narratief-tekste van 2 Makkabeërs 3. Deur gebruik te maak van die narratiefterapeutiese benadering van Epston en White, kom hy tot die gevolgtrekking dat 2 Makkabeërs 3 'n aanduiding is dat God positief reageer wanneer die hoëpriester en die volk Hom eendragtig aanbid, en wanneer hulle bereid is om vreemde indringers en hulle ideologieë uit die tempel weg te weer.

G.J.C. (Jorrie) Jordaan ondersoek in sy bydrae die verwysing in Hebreërs 12:24 na die besprinkelingsbloed wat van beter dinge getuig as die bloed van Abel. Deur 'n vergelyking met relevante getuienis elders in die Skrif, veral met die geskiedenis van Kain en Abel in Genesis 4, kom hy tot die gevolgtrekking dat die bloed van die vermoorde Abel 'n getuienis was dat die mensdom ná die sondeval in sonde ontvang en gebore is en daarom vir die oordeel en straf van God bestem is. Die bloed van offerdiere, wat volgens God se verbondsbepalings oor die volk gesprinkel moes word (Eks 24:8), was egter 'n getuienis van die belofte van skuldvergewing en versoening. Hierdie belofte het in Jesus Christus in vervulling gegaan, sodat Jesus onder meer in Hebreërs 12:24 die Middelaar van 'n nuwe verbond genoem word. 